\title{
Correction to: Comparison of the Skin Cancer Quality of Life Impact Tool and the Skin Cancer Index Questionnaire in Measurement of Health-Related Quality of Life and the Effect of Patient Education Brochures in Patients with Actinic Keratosis, Non- melanoma Skin Cancer, and Cutaneous Melanoma
}

\author{
Sam El Abbadi · Laura Susok · Egger Stockfleth · Falk Georges Bechara • \\ Thilo Gambichler · Swetlana Herbrandt · Lisa Goldschmidtböing • \\ Michael Sand
}

Published online: May 6, 2021

(c) The Author(s) 2021

Correction to: Dermatol Ther (Heidelb)

https://doi.org/10.1007/s13555-021-00522-y

Authors would like to correct the error in article title. Correct version of title updated here.

The original article has been corrected.

The original article can be found online at https://doi. org/10.1007/s13555-021-00522-y.

\section{S. El Abbadi}

Department of Plastic, Reconstructive, Aesthetic and Hand Surgery, University Hospital OWL, Campus Klinikum Bielefeld Center, Bielefeld, Germany

L. Susok · E. Stockfleth · F. G. Bechara .

T. Gambichler · M. Sand $(\varangle)$

Department of Dermatology, Venereology and

Allergology, Ruhr-University Bochum, Bochum, Germany

e-mail: michael.sand@ruhr-uni-bochum.de

\section{S. Herbrandt · L. Goldschmidtböing}

Department for Statistical Consulting and Analysis, Center for Higher Education, Technical University of Dortmund, Dortmund, Germany

M. Sand

Department of Plastic, Reconstructive and Aesthetic Surgery, St. Josef Hospital, Essen, Germany

\begin{abstract}
Open Access. This article is licensed under a Creative Commons Attribution-NonCommercial 4.0 International License, which permits any non-commercial use, sharing, adaptation, distribution and reproduction in any medium or format, as long as you give appropriate credit to the original author(s) and the source, provide a link to the Creative Commons licence, and indicate if changes were made. The images or other third party material in this article are included in the article's Creative Commons licence, unless indicated otherwise in a credit line to the material. If material is not included in the article's Creative Commons licence and your intended use is not permitted by statutory regulation or exceeds the permitted use, you will need to obtain permission directly from the copyright holder. To view a copy of this licence, visit http:// creativecommons.org/licenses/by-nc/4.0/.
\end{abstract}

